\title{
Rapidly involuting congenital haemangioma in a term neonate
}

\author{
Maitrayee Thoppay Kumarasamy, Garifalia Castrisios, Bal Krishana Sharma
}

Department of Paediatrics and Neonatology, Barking, Havering and Redbridge University Hospitals NHS Trust, Romford, UK

\section{Correspondence to Dr Garifalia Castrisios, gcastrisios@gmail.com}

Accepted 30 March 2014

\section{CrossMark}

\section{To cite: Thoppay}

Kumarasamy $\mathrm{M}$

Castrisios G, Sharma BK. BMJ Case Rep Published online: [please include Day Month Year] doi:10.1136/ bcr-2013-203233

\section{DESCRIPTION}

Following an uncomplicated pregnancy with normal antenatal scans, a term neonate was unexpectedly born with a large mass on the right temporal region (figure 1). This caused extreme anxiety among staff regarding the possibility of encephalocoele or meningocoele. Examination revealed a soft, compressible mass, with no midline defect. Subsequently, cranial ultrasonogram demonstrated no extracranial extension of brain tissue, and normal ventricles. MRI confirmed a haemangioma with no evidence of intracranial extension and normal brain parenchyma. The infant was haemodynamically stable with a normal platelet count. Rapidly involuting congenital haemangioma (RICH) was diagnosed following review by plastic surgeons. The haemangioma completely regressed by 7 months, resulting in redundant skin and distortion of the pinna requiring reconstructive surgery (figure 2).

Congenital haemangiomas are rare lesions that are fully developed at birth. They are classified into two types: RICH and non-involuting congenital haemangiomas. Their combined incidence is less than $3 \%$ of the more commonly occurring nascent infantile haemangiomas. ${ }^{1}$ The natural course is characterised by spontaneous and complete resolution within 6-14 months. ${ }^{1}{ }^{2}$ Histopathologically, unlike infantile haemangiomas, congenital haemangiomas stain negative for glucose transporter-1 protein. ${ }^{1}{ }^{2}{ }^{3}$ The management of RICH includes expectant observation, assessment of haemodynamic status and wound care. Surgical excision is indicated for persistent ulceration or development of Kasabach Merritt phenomenon in medically resistant lesions. Lesions that do not follow the expected course require biopsy/excision to distinguish from malignant tumours.

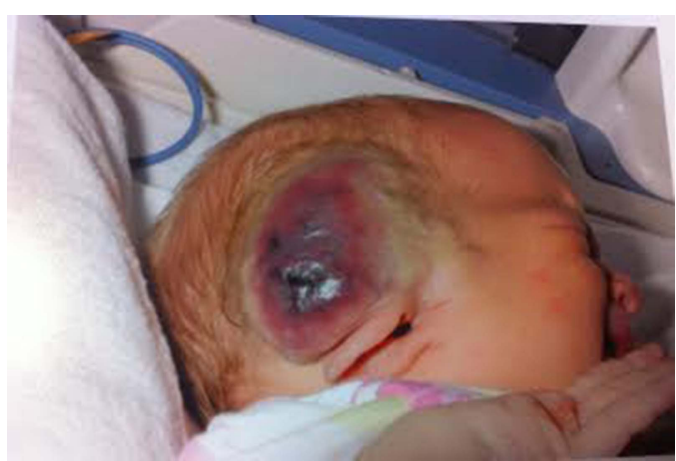

Figure 1 Large haemangioma over the right temporal region; taken on day 3 of life showing distortion of the pinna.

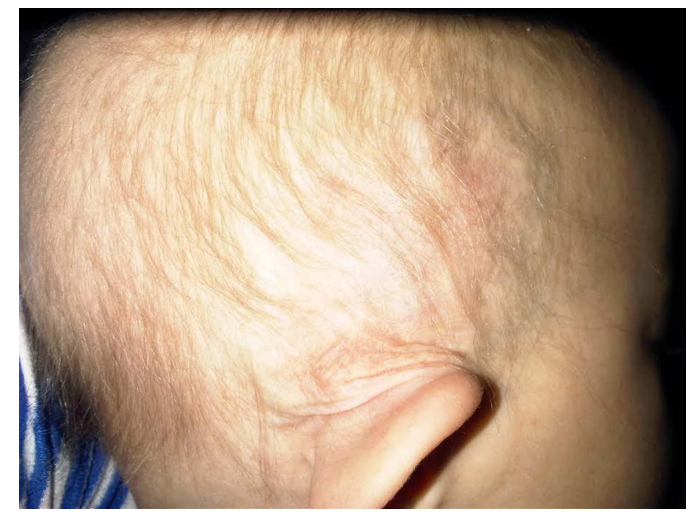

Figure 2 Involuting congenital haemangioma at 6 months of age resulting in redundant skin and distortion of the right pinna.

This case highlights rare congenital haemangiomas and emphasises the need for multidisciplinary input for diagnosis and management.

\section{Learning points}

- The importance of multidisciplinary teams for the diagnosis and management.

- Identification of rarer haemangiomas from common haemangiomas by their natural history.

- Haemangiomas should be monitored, if they do not follow their expectant course biopsyl excision should be considered to exclude malignancy.

- A platelet count should be checked in large haemangiomas.

- Patients with large haemangiomas should be examined for signs of heart failure.

Contributors The case was identified by BKS. All authors were involved in writing the report.

Competing interests None.

Patient consent Obtained.

Provenance and peer review Not commissioned; externally peer reviewed.

\section{REFERENCES}

1 Krol A, MacArthur CJ. Congenital hemangiomas: rapidly involuting and noninvoluting congenital haemangiomas. Arch Facial Plast Surg 2005;7:307-11.

2 Restrepo R, Palani R, Cervantes LF, et al. Hemangiomas revisited: the useful, the unusual and the new: part 1: overview and clinical and imaging characteristics. Pediatr Radiol 2011;41:895-904.

3 Puttgen $\mathrm{KB}$, Pearl $\mathrm{M}$, Tekes $\mathrm{A}$, et al. Update on pediatric extracranial vascular anomalies of the head and neck. Childs Nerv Syst 2010;26:1417-33. 


\section{Images in...}

Copyright 2014 BMJ Publishing Group. All rights reserved. For permission to reuse any of this content visit http://group.bmj.com/group/rights-licensing/permissions.

BMJ Case Report Fellows may re-use this article for personal use and teaching without any further permission.

Become a Fellow of BMJ Case Reports today and you can:

- Submit as many cases as you like

- Enjoy fast sympathetic peer review and rapid publication of accepted articles

- Access all the published articles

- Re-use any of the published material for personal use and teaching without further permission

For information on Institutional Fellowships contact consortiasales@bmjgroup.com

Visit casereports.bmj.com for more articles like this and to become a Fellow 